\title{
Zinc Finger Protein 703
}

National Cancer Institute

\section{Source}

National Cancer Institute. Zinc Finger Protein 703. NCI Thesaurus. Code C95870.

Zinc finger protein 703 (590 aa, $\sim 58 \mathrm{kDa}$ ) is encoded by the human ZNF703 gene. This protein may play a role in the modulation of gene transcription. 